\title{
Properties of crude laccase from Trametes versicolor produced by solid-substrate fermentation
}

\author{
Ivanka Stoilova $^{1}$, Albert Krastanov ${ }^{1}$, Veselin Stanchev ${ }^{2}$ \\ ${ }^{1}$ Department of Biotechnology, University of Food Technologies, Plovdiv, Bulgaria; \\ ${ }^{2}$ Department of Automatics, Information and Control Systems, University of Food Technologies, Plovdiv, Bulgaria. \\ Email: abt-kr@ rocketmail.com
}

Received 7 April 2010; revised 22 April 2010; accepted 25 April 2010.

\begin{abstract}
A low-cost process for the production of laccases is necessary for a sustainable enzymatic wastewater treatment. Therefore, it is necessary to establish an easy and low-cost procedure for the production of laccase. In the present study the properties of crude laccase from Trametes versicolor produced by solidsubstrate fermentation is investigated. The application of the enzyme for dye decolorization is also studied. Crude laccase from the studied culture established maximal activity at $45^{\circ} \mathrm{C}$. The enzyme retained over $90 \%$ of its activity in the temperature range 40$47^{\circ} \mathrm{C}$ and $\mathrm{pH}$ 4.5. The kinetic constants of the crude enzyme was also determined. In the presence of $\mathrm{KCl}$, $\mathrm{NaCl}, \mathrm{CaCl}_{2}, \mathrm{MnSO}_{4}$ and $\mathrm{MgSO}_{4}$, laccase demonstrated high stability-over $50 \%$ of its initial activity was still retained after 4-month incubation. Complete loss of enzymatic activity was observed in the presence of $\mathrm{CuCl}_{2}, \mathrm{FeCl}_{2}, \mathrm{FeCl}_{3}$ and $\mathrm{NaN}_{3}$ after $30 \mathrm{~min}$ of incubation. $100 \%$ decolorization by investigated crude laccase was completed in the case of Indigo Carmine for $4 \mathrm{~h}$, Remazol Brilliant Blue R-for $6 \mathrm{~h}$, Orange IIfor $48 \mathrm{~h}$ and Congo Red-for $13 \mathrm{~d}$.
\end{abstract}

Keywords: Laccase; Solid-Substrate Fermentation; Trametes versicolor; Dye Decolorization

\section{INTRODUCTION}

Laccases (benzenediol:oxygen oxidoreductase, EC 1.10. 3.2) are extracellular, multicopper enzymes that use molecular oxygen to oxidize various aromatic and nonaromatic compounds by a radical-catalysed reaction mechanism [1]. Laccases can convert $o$-and $p$-diphenols, aminophenols, methoxy-substituted phenols, benzenethiols, polyphenols, polyamines, hydroxyindols, some aryl diamines and a considerable range of other compounds but do not oxidize tyrosine (whereas the tyrosina ses do).

Laccases can be very strongly inhibited by various reagents. Small anions such as azide, halides, cyanide, thiocyanide, fluoride and hydroxide bind to the type 2 and type $3 \mathrm{Cu}$, resulting in the interruption of internal electron transfer and inhibition of activity. Other inhibitors include metal ions (e.g. $\mathrm{Hg}^{2+}$ ), fatty acids, sulfhydryl reagents, hydroxyglycine, kojic acid, desferal and cationic quaternary ammonium detergents the reactions with which may involve amino acid residue modifications, conformational changes or $\mathrm{Cu}$ chelation [2,3]. Regarding conformational changes, it is known that these are highly dependent on the state of oxidation of the copper atoms. Laccases generally are more stable at alkaline $\mathrm{pH}$ than at acidic $\mathrm{pH}$, probably due to the $\mathrm{OH}^{-}$inhibition of autooxidation.

Laccases are increasingly being used in a wide variety of industrial oxidative processes such as delignification, dye or stain bleaching, bioremediation, plantfibre modification, ethanol production, biosensors, biofuel cells, etc. Industrial uses require overproduction of the enzyme, generally in a heterologous host, as an indispensable prerequisite. Indeed, most commercial laccases are produced in Aspergillus hosts. The functional expression of the Myceliophthora thermophila laccase in S. cerevisiae by directed molecular evolution has been reported, which enables this system to be tuned up for new and challenging applications [4]. Many white-rot fungi produce multiple laccase isoforms under the appropriate inductive conditions [5,6]. Most fungal laccases studied are extracellular proteins, but intracellular laccases have been detected in some fungi [7].

The genus Trametes, which belongs to the white-rot fungi, is assumed to be one of the main producers of laccases. T. versicolor produces laccase and $\mathrm{MnP}$ as major ligninolytic enzymes; however, the role of these enzymes in decolorization of azo dyes is not yet clear. Laccase and/or $\mathrm{MnP}$ activities in culture filtrate of $T$. versicolor were not able to decolorize azo dyes, thus indicating a role of other enzymes or cell-bound components in azo dye degradation [8]. 
In order to produce laccases, white-rot fungi have to be cultured under specific conditions. Two types of culture techniques are used: Solid-state fermentation (SSF) and Submerged fermentation (SmF). The SSF is defined as any fermentation process occurring in absence or near absence of free liquid, using an inert substrate or a natural substrate as a solid support [9]. The former works as an attachment place for the microorganism, whereas the latter also acts as a carbon source, which considerably reduces the production costs [10]. SSF is advantageous in obtaining concentrated metabolites and subsequent purification procedures are economical $[11,12]$. In SSF, the microorganisms grow under conditions close to their natural habitat. This may allow them to produce certain enzymes and metabolites, which usually would not be produced or would only be produced at a low yield in $\mathrm{SmF}$ [9]. Therefore, the selection of an adequate support is essential, since the success of the process depends on it.

Laccases have become important, industrially relevant enzymes that can be used for a number of diverse applications, including biocatalytic purposes such as delignification of lignocellulosics and crosslinking of polysaccharides, bioremediation applications such as waste detoxification and textile dye transformation [13], food technological uses, personal and medical care applications [14], and biosensor and analytical applications [15]. In view of the broad biotechnological applications of laccases [16-18], there is a scientific need to identify different sources of laccases having diverse properties so that suitable laccases for various applications could be identified.

The enzymatic treatment of wastewater requires the production of large amounts of enzymes, in this case laccases, at low cost. The current commercial price of laccases is high, constituting a drawback for its use. A low-cost process for the production of laccases is necessary for a sustainable enzymatic wastewater treatment. Therefore, it is necessary to establish an easy and low-cost procedure for the production of laccase. In the present study the properties of crude laccase from SSF culture of Trametes versicolor is investigated. The application of the enzyme for dye decolorization is also studied.

\section{MATERIALS AND METHODS}

\subsection{Microorganisms and Inoculum}

A fungal strain of Trametes versicolor 1A collected from hills in the city of Plovdiv, Bulgaria was used in this work. The culture belongs to the collection of the Department of "Biotechnology" at the University of Food Technologies in Plovdiv-Bulgaria. The culture is main- tained on $2 \%$ lima bean agar plates and slants at $4^{\circ} \mathrm{C}$. For enzyme production, a 7-day old plate culture grown on $2 \%$ potato dextrose agar (PDA) was used. Mycelial inoculum was prepared by inoculating $10^{7}$ spores of fungus from agar-slant culture to $300 \mathrm{ml}$ shake flask containing $50 \mathrm{ml}$ beer must $7.5^{\circ} \mathrm{B}$. The $\mathrm{pH}$ of the media was adjusted with $1 \mathrm{M} \mathrm{NaOH}$ to 6.5. The inoculated flasks were incubated at $30^{\circ} \mathrm{C}$ and $220 \mathrm{rpm}$ for $72 \mathrm{~h}$.

\subsection{Solid-Substrate Fermentation (SSF)}

The SSF was carried out using a medium consisted of $4.0 \mathrm{~g}$ wheat bran, $2.5 \mathrm{~g}$ oats straw and $2.5 \mathrm{~g}$ beetroot press in $300 \mathrm{ml}$ flasks. The moist of the substrate was adjusted to $60 \%$ by salt solution containing (\%): $\left(\mathrm{NH}_{4}\right)_{2} \mathrm{SO}_{4}-0.14 ; \mathrm{KH}_{2} \mathrm{PO}_{4}-0.2 ; \mathrm{MgSO}_{4} \cdot 7 \mathrm{H}_{2} \mathrm{O}-0.03$; $\mathrm{CaCl}_{2}-0.03 ; \mathrm{FeSO}_{4} .7 \mathrm{H}_{2} \mathrm{O}, \mathrm{ZnSO}_{4} \cdot 7 \mathrm{H}_{2} \mathrm{O}, \mathrm{MnSO}_{4} .7 \mathrm{H}_{2} \mathrm{O}$ and $\mathrm{CoCl}_{2}-0.002(\mathrm{pH} 4.5)$. After autoclaving $\left(121^{\circ} \mathrm{C}\right.$ for $30 \mathrm{~min}$ ) and cooling, the substrate was inoculated with the appropriate mycelial inoculum prepared as mentioned above. SSF fermentation with monocultures was used as reference. All flasks were cultivated at $30^{\circ} \mathrm{C}$ for 7 days. Triplicate flaks were set up for each experimental variation.

\subsection{Enzyme Extraction}

The crude enzyme extract was obtained by adding $50 \mathrm{ml}$ distilled water to the fermented matter. The flasks were mixed for $30 \mathrm{~min}$ at room temperature $\left(25^{\circ} \mathrm{C}\right)$ using a shaker $(220 \mathrm{rpm})$. Solids were removed first by filtering and then by centrifuging at $5000 \mathrm{~g}$ for $5 \mathrm{~min}$. The supernatant obtained was used as crude enzyme extract.

\subsection{Laccase Activity Measurement}

Laccase activity was assayed according to Marbah et al. [20] using syringaldazine as a substrate. One unit of laccase activity was defined as $0.001 \Delta \mathrm{A}_{530}$ for $1 \mathrm{~min}, \mathrm{pH}$ 4.5 and $30^{\circ} \mathrm{C}$.

\subsection{Determination of the Kinetic Parameters ( $K_{m}$ and $V_{\max }$ ) of the Enzyme}

$K_{m}$ and $V_{\max }$ values were determined using 4-hydroxy-3,5-dimethoxybenzaldehyde azine (syringaldazine) and 2,2'-azinobis-3-ethylbenzothiazoline-6-sulfonic acid (ABTS) as substrates [20] at different concentrations $(0.01 \div 0.1 \mathrm{mM})$ in $0.2 \mathrm{M}$ citrate-phosphate buffer $(\mathrm{pH}$ $4.5)$. The computing procedures were performed by using a package of applied software programs of own development in the software media of Matlab and Eureka $[21,22]$. For analyzing the results two approaches were used:

$$
\text { Michaelis-Menten } v=V_{\max } \frac{S(t)}{k_{m}+S(t)}
$$


Reversible substrate inhibition

$$
v=V_{\text {max }} \frac{S(t)}{k_{m}+S(t)+S^{2}(t) / k_{i}}
$$

The kinetic parameters in each of the models were calculated according to the optimization procedure which minimized a criterion of the type:

$$
J=\sum_{i=1}^{n}\left(v_{\text {opit }, i}-v_{\bmod , i}\right)^{2} \rightarrow \min ,
$$

where $v$ is the initial velocity of the enzyme reaction calculated by (1) and (2) and $n$ is the number of analyzing points.

\subsection{Effect of Ph on the Activity and Stability of the Enzyme}

Laccase activity is a function of $\mathrm{pH}$ measured in $0.2 \mathrm{M}$ citrate-phosphate buffer over the range from 1.8 to 6.6. The highest activity was set as $100 \%$ of relative activity. For the stability experiments, the crude extract was incubated under initial conditions for 30 minutes at $30^{\circ} \mathrm{C}$ and residual laccase activity was determined at intervals according to the standard conditions cited above. The buffers used in that study were: citrate $(\mathrm{pH} 3.0,3.5,4.0)$, acetate $(\mathrm{pH} 4.0,4.5,5.0,5.5)$, phosphate $(\mathrm{pH} 5.5,6.0$, $6.5,7.0)$.

\subsection{Effect of Temperature on the Activity and Stability of the Enzyme}

Laccase activity was measured at $\mathrm{pH} 4.5$ in $0.2 \mathrm{M}$ citrate-phosphate buffer at different temperatures over the range $10-70^{\circ} \mathrm{C}$. The enzyme's thermal stability was assayed by incubating the crude extract at different temperatures in the range of $30-70^{\circ} \mathrm{C}$ at different times using $0.2 \mathrm{M}$ citrate-phosphate buffer. After the incubation, the crude extract was cooled and laccase activity was determined at standard conditions.

\subsection{Effect of Ions}

The crude extract was incubated with different ionic solutions: $\mathrm{KCl}, \mathrm{ZnCl}_{2}, \mathrm{CuCl}, \mathrm{Pb}\left(\mathrm{NO}_{3}\right)_{2}, \mathrm{AgNO}_{3}, \mathrm{ZnSO}_{4}$, $\mathrm{MgSO}_{4}, \mathrm{MnSO}_{4}, \mathrm{NaCl}$ and $\mathrm{CaCl}_{2}$ at $10 \mathrm{mM} ; \mathrm{NaN}_{3}$ at 1.0 $\mathrm{mM}$ and residual laccase activity was determined at intervals according to the standard conditions cited above with syringaldazine as substrate. The activity of the enzyme immediately after ultrafiltration was set as $100 \%$ of relative activity.

\subsection{Removing of Salts (Ultrafiltration)}

Removing of salts in crude enzyme extract was carried out in ultrafiltration module by pressure of nitrogen of $0.3 \mathrm{MPa}$. Cellulose acetate membrane (500 Da) was used. The crude enzyme extract was rinsed and filtered until conductivity of $56 \mu \mathrm{S}$ was achieved (Tungsram's "Ra- delkis" conductometer).

\subsection{Dye Decolorization Studies}

Crude enzyme extract was collected at the maximum laccase activity (day 7), filtered, clarified by centrifugation at $8000 \mathrm{~g}$ for $15 \mathrm{~min}$, frozen, defrosted and then filtered to remove the precipitated polysaccharides. The resulting clear filtrate was concentrated by ultrafiltration (as described above). In vitro decolorization experiments were performed with the concentrated clear filtrate. For the purpose of the investigation the crude enzyme extract was diluted twice, thus we used two samples-with 2000 and $1000 \mathrm{U} / \mathrm{ml}$ laccase activity. The dyes tested for the in vitro studies were: indigo carmine (indigoid) CI 73015, phenol red (sulfonaphthalein), Remazol Brilliant Blue R, and the azo-dyes Orange II and Congo Red. All were purchased from Aldrich (St. Louis, MO, USA) and were used in a concentration of $0.01 \%$. The reaction mixture for dye decolorization consisted of equal volumes of an aqueous solution of dye and crude laccase ( 2000 or $1000 \mathrm{U} / \mathrm{ml}$ ) in citrate phosphate buffer (pH 5.0). The residual dye concentration was measured spectrophotometrically at $608 \mathrm{~nm}$ for indigo carmine, $587 \mathrm{~nm}$ for Remazol Brilliant Blue R, $483 \mathrm{~nm}$ for Orange II, 497 $\mathrm{nm}$ for Congo Red and $475 \mathrm{~nm}$ for phenol red. A control test containing the same amount of a heatdenatured laccase was performed in parallel. The assays were done thrice, the experimental error being below $3 \%$.

\section{RESULTS AND DISCUSSIONS}

\subsection{Effect of $\mathrm{pH}$ and Temperature on Laccase Activity and Stability}

Most of the fungal laccase have optimum $\mathrm{pH}$ in the range of 3.0-4.0 and temperature in the range of $40-60^{\circ} \mathrm{C}$ for oxidation of phenolic compounds. Crude laccase produced by Trametes versicolor $1 \mathrm{~A}$ was found to express maximal activity at $\mathrm{pH} 4.5$ (Figure 1(a)). The enzyme activity was also high in the $\mathrm{pH}$ range between 4.1 and 4.8, being respectively $99.3 \%$ and $95.2 \%$ of the maximum. Crude laccase was proved active in the range of $\mathrm{pH}$ modification from 3.3 to 6.0 .

Crude laccase from the studied culture established maximal activity at $45^{\circ} \mathrm{C}$ (Figure 1(b)). The enzyme retained over $90 \%$ of its activity in the temperature range $40-47^{\circ} \mathrm{C}$, the respective values being $94.2 \%$ and $93.3 \%$ of the maximum. Within the range $30-50^{\circ} \mathrm{C}$ the loss of enzymatic activity was below $30 \%$, and in particular$28.9 \%$ and $23.2 \%$. At $60^{\circ} \mathrm{C}$ the loss of laccase activity was $83.6 \%$.

In the range of $\mathrm{pH}$ values between 3.0 and 7.0 the enzyme was found to be most stable at $\mathrm{pH} 4.5$ (Figure 2(a)). During the 48-hour follow-up of the investigation the enzyme activity was found to decrease only by $3.4 \%$. 


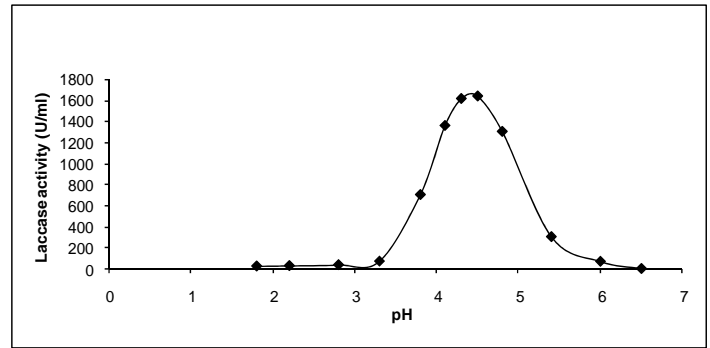

(a)

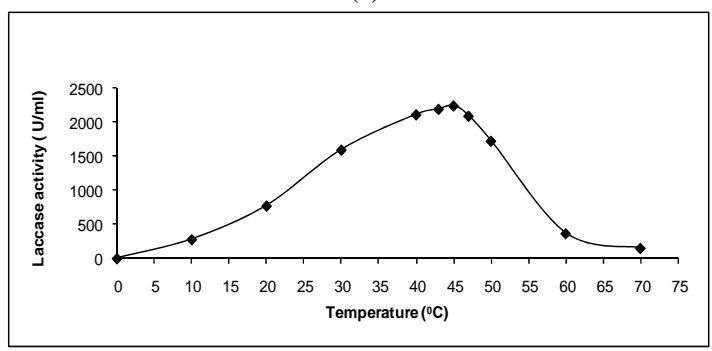

(b)

Figure 1. Effect of $\mathrm{pH}$ (a) and temperature (b) on the activity of the enzyme.

Minor losses of enzyme activity were registered at $\mathrm{pH}$ 5.0 and 5.5 , as well, namely $7.1 \%$ and $9.2 \%$ for $48 \mathrm{~h}$. Crude laccase was assessed as being most unstable at $\mathrm{pH}$ 7.0 - the reduction of enzymatic activity was by $57.2 \%$ for $48 \mathrm{~h}$.

The thermal stability of crude laccase was followed within the temperature interval $30-60^{\circ} \mathrm{C}$ (Figure 2(b)). The greatest stability of the enzyme was observed at $30^{\circ} \mathrm{C}$ - the residual activity after $48 \mathrm{~h}$ incubation was $97.2 \%$. The enzyme was still stable at $40^{\circ} \mathrm{C}$ - the loss of enzymatic activity for the same period of incubation was $9.8 \%$. At $50^{\circ} \mathrm{C}$ the losses of enzymatic activity were $53.4 \%$ for $6 \mathrm{~h}$ and $90.0 \%$ for $48 \mathrm{~h}$ incubation. After $6 \mathrm{~h}$ incubation at $60^{\circ} \mathrm{C}$ the loss of activity reached $58.0 \%$, while after $48 \mathrm{~h}$ incubation no enzymatic activity was registered. At $70^{\circ} \mathrm{C}$ the enzyme had lost $53.5 \%$ of its initial activity in $5 \mathrm{~min}$, and had been completely inactivated in $20 \mathrm{~min}$ (data not shown).

\subsection{Kinetic Analysis}

Two compounds, ABTS and syringaldazine, were used as substrates for measuring the kinetic constants of crude laccase. The results from the investigation of process dynamics in the case of ABTS and syringaldazine as substrates are presented in Table 1.

The conditions for setting in the establishment of substrate inhibition are specified in (2): $\left(S_{\text {crit. }}=\right.$ $\left.\sqrt{k_{s} \cdot k_{i}}\right)$. That correlation, as well as (3), was used as the grounds for an a priori choice of model type. The values of the kinetic parameters calculated by the two models, and the values of $J$ and $S_{\text {crit. }}$ criteria for

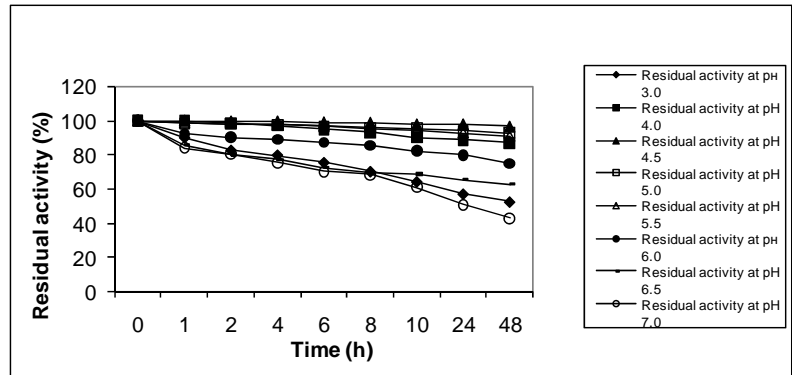

(a)

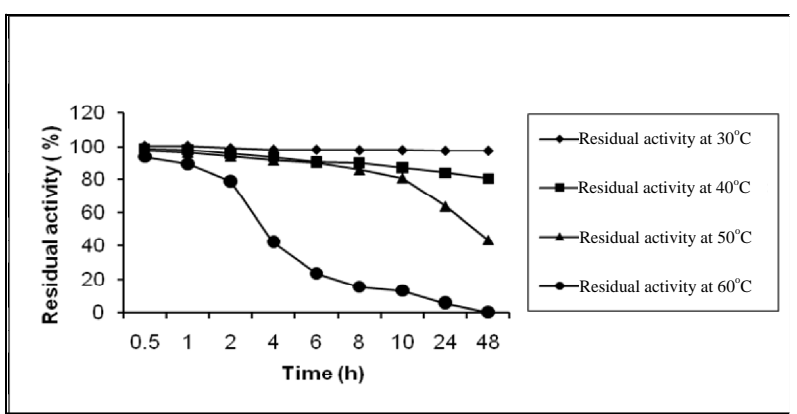

(b)

Figure 2. Effect of pH (a) and temperature (b) on the stability of crude laccase.

the substrates ABTS and syringaldazine are presented in Table 2.

For ABTS substrate the value of the parameter $J$ calculated by model (2) was one order below that obtained by model (1). On the other hand, So $=0.1[\mathrm{mM}]$ turned to be only $10 \%$ lower than. $S_{\text {crit. }}$ Therefore, in the case of ABTS substrate, more appropriate descriptor of process dynamics proves to be the model taking into account the presence of reversible substrate inhibition (2).

For syringaldazine, model (1), was found to be more suitable for investigating the dynamics of the enzymatic reaction, since the value of $J$ was once again an order below the value obtained by model (2) but So $=0.1[\mathrm{mM}]$ was noticeably lower than $S_{\text {crit. }}=$ 0.145 (by. $45 \%$ )-i.e. in that case there was a marked substrate limitation under the conditions of the experiment.

The kinetic constants determined are quite comparable with those reported for other Trametes spp. The value of $K_{m}$ obtained for sustrate ABTS was identical with the data announced for laccase from $T$. trogii [23] but disagreed with the value cited for laccase from Pycnoporus sanguineus SCC 108 [24].

The $K_{m}$ index for syringaldazine substrate was lower than the value of the index established for ABTS substrate, pointing out the greater affinity of the investigated 
Table 1. Dynamics of the process using model (1) and (2) for ABTS and Syringaldazine.

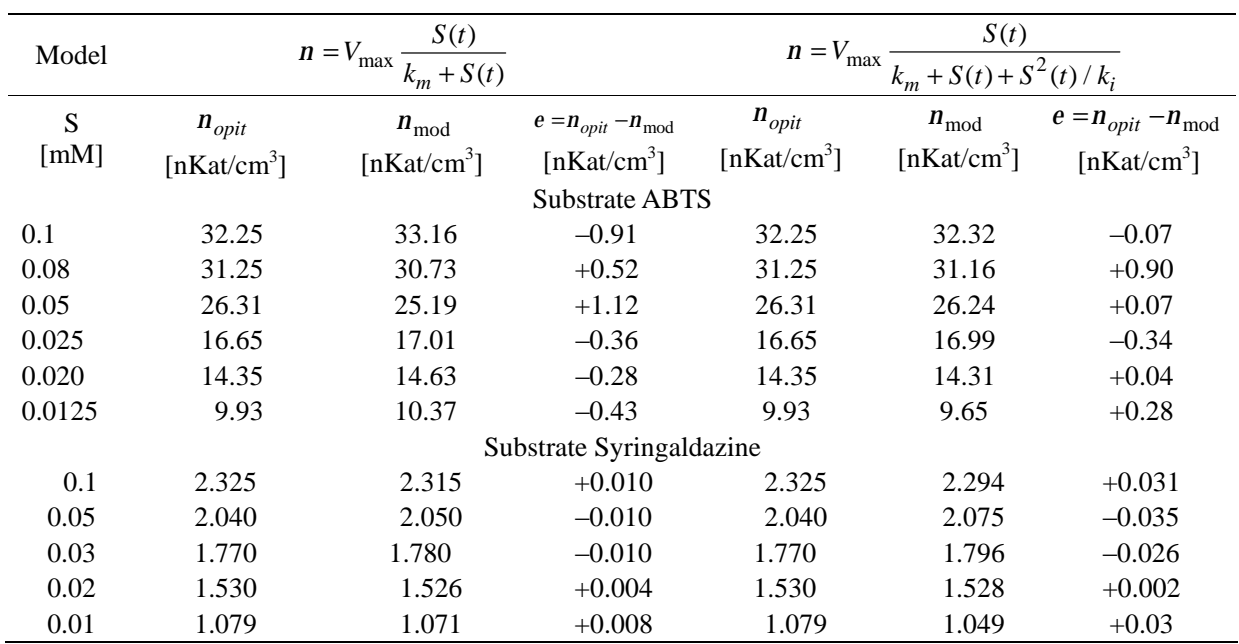

Table 2. Kinetic constant using model (1) and (2) for ABTS and Syringaldazine.

\begin{tabular}{ccccc}
\hline & \multicolumn{3}{c}{ Substrate } & \multicolumn{3}{c}{ Syringaldazine } \\
\cline { 2 - 5 } Kinetic constant & model (1) & model (2) & model (1) & model (2) \\
\hline$V_{\max }$ & 48.52 & 91.4100 & 2.6570 & 2.8820 \\
$k_{m}$ & 0.0463 & 0.1047 & 0.0148 & 0.0174 \\
$k_{i}$ & - & 0.1280 & - & 1.2130 \\
$J$ & 2.72 & 0.2097 & $3.67 \mathrm{e}^{-4}$ & $3.76 \mathrm{e}^{-3}$ \\
$S_{\text {crit. }}$ & - & 0.116 & - & 0.145 \\
\hline
\end{tabular}

Table 3. Effect of ions on enzyme activity.

\begin{tabular}{|c|c|c|c|c|c|c|c|}
\hline \multirow{2}{*}{$\begin{array}{c}\text { Salts } \\
(10 \mathrm{mM})\end{array}$} & \multicolumn{7}{|c|}{ Residual activity (\%) } \\
\hline & \multicolumn{2}{|c|}{1 day } & 1 month & \multicolumn{2}{|c|}{2 months } & 3 months & 4 months \\
\hline Control & \multicolumn{2}{|c|}{100} & 68.54 & 52.51 & \multicolumn{2}{|c|}{22.92} & 0 \\
\hline $\mathrm{KCl}$ & \multicolumn{2}{|c|}{96.35} & 90.36 & 86.44 & \multicolumn{2}{|c|}{59.60} & 52.72 \\
\hline $\mathrm{NaCl}$ & \multicolumn{2}{|c|}{112.38} & 91.26 & 87.40 & \multicolumn{2}{|c|}{75.70} & 74.53 \\
\hline $\mathrm{CaCl}_{2}$ & \multicolumn{2}{|c|}{111.69} & 94.01 & 94.01 & \multicolumn{2}{|c|}{73.36} & 68.82 \\
\hline $\mathrm{MnSO}_{4}$ & \multicolumn{2}{|c|}{111.69} & 83.00 & 66.96 & \multicolumn{2}{|c|}{59.87} & 51.24 \\
\hline $\mathrm{MgSO}_{4}$ & \multicolumn{2}{|c|}{95.87} & 53.40 & 40.12 & \multicolumn{2}{|c|}{35.99} & 28.42 \\
\hline \multirow[t]{2}{*}{$\mathrm{ZnSO}_{4}$} & \multicolumn{2}{|c|}{109.63} & 87.81 & 39.23 & \multicolumn{2}{|c|}{0} & \\
\hline & 1 day & 5 days & 10 days & 15 days & 20 days & 25 days & 30 days \\
\hline $\mathrm{ZnCl}_{2}$ & 68.82 & 46.11 & 22.29 & 17.41 & 9.84 & 5.02 & 0 \\
\hline $\mathrm{CuCl}$ & 64.69 & 34.13 & 22.71 & 5.71 & 0 & & \\
\hline $\mathrm{Pb}\left(\mathrm{NO}_{3}\right)_{2}$ & 66.75 & 66.07 & 29.59 & 24.50 & 2.75 & 2.06 & 0 \\
\hline $\mathrm{AgNO}_{3}$ & 85.57 & 45.83 & 386 & 26.56 & 3.16 & 0 & \\
\hline
\end{tabular}

After $30 \mathrm{~min}$ the enzyme was fully inactivated by: $\mathrm{NaN}_{3}, \mathrm{CuCl}_{2}, \mathrm{FeCl}_{2}, \mathrm{FeCl}_{3}$

laccase to the first of the substrates.

\subsection{Effect of Ions on Enzyme Activity}

Laccase in crude enzyme extract (control) was found to lose its activity after an incubation period of 3 months (Table 4). In the presence of 5 of the investigated salts$\mathrm{KCl}, \mathrm{NaCl}, \mathrm{CaCl}_{2}, \mathrm{MnSO}_{4}$ and $\mathrm{MgSO}_{4}$, laccase demonstrated high stability—over $50 \%$ of its initial activity was still retained after 4-month incubation. It has been assumed that in the presence of various salts enzymes are more substantially influenced by cations. Data from our study revealed that the strongest positive impact on enzyme's molecule was exercised by $\mathrm{Na}(\mathrm{I})$ ions, ensuring the molecule stabilization for a period of 4 months with the least loss of enzymatic activity-25\%.

On the other extreme was the effect of $\mathrm{Zn}(\mathrm{II})$ and $\mathrm{Cu}(\mathrm{I})$ ions introduced into the medium as chlorides - their 
availability destabilized the enzyme molecule making it much more unstable than crude laccase; in the presence of the above cited salts a complete loss of enzymatic activity was registered after 25 and $15 \mathrm{~d}$ (in the respective case). In principle, heavy metals have been known to posses a negative impact on enzymes and this was confirmed by the results from our study. It is a clear fact, however, that their destabilizing influence does not go beyond the influence of $\mathrm{ZnCl}_{2}$ and $\mathrm{CuCl}$.

The suggestion that $\mathrm{Na}(\mathrm{I})$ added in the form of $\mathrm{NaCl}$ have a positive effect in terms of laccase stability was not confirmed by the experiment with $\mathrm{NaN}_{3}$, in which after $30 \mathrm{~min}$ of treatment a complete loss of enzymatic activity was registered. It could be assumed that in the specific case dominated the influence of the respective anion. Azide is a very effective inhibitor of laccase II, and complete inhibition was observed with $1.0 \mathrm{mM}$ $\mathrm{NaN}_{3}$. Azide is thought to bridge both the type 2 and type $3 \mathrm{Cu}$ in laccase. Our results are with correspondence with $[25,26]$. They reported for full or $98 \%$ inhibition of laccase activity of some basidiomycetes and ascomycetes by $1.0 \mathrm{mM}$ sodium azide but for shorter period of time to compare to our crude enzyme.

Complete loss of enzymatic activity was observed in the presence of $\mathrm{CuCl}_{2}, \mathrm{FeCl}_{2}$ and $\mathrm{FeCl}_{3}$ after 30 min of incubation, suggesting that $\mathrm{Cu}$ (I) and $\mathrm{Cu}$ (II) had a negative impact on the enzyme, regardless of being its cofactors. Probably that finding could be attributed to the high concentration of the introduced salts.

\subsection{Dye Decolorization Studies}

The ability of white-rot fungi to decolorize synthetic dyes has been widely studied, particularly with Phanerochaete chrysosporium and Trametes versicolor [27]. In the present study, we assessed the ability of the crude laccase (extracted fluid) from SSF culture of $\mathrm{T}$. versicolor, to decolorize five structurally different synthetic dyes. The decoloration of type model dyes is a simple method to assess the aromatic degrading capability of ligninolytic enzymes [28]. Dye decolorization by laccase is a property of the crude enzyme that underlies one of its possible applications. The results concerning dye decolorization by laccase with enzymatic activities of 1000 and 2000 $\mathrm{U} / \mathrm{ml}$ are presented on Figures 3(a) and (b). The application of enzyme solutions with higher activity proved better results for each of the five dyes studied. As it can be seen in Figure 3, the decoloration rate obtained was very different in each case. $100 \%$ decolorization by laccase (2000 U/ml activity) was completed in the case of Indigo Carmine for $4 \mathrm{~h}$, Remazol Brilliant Blue R-for $6 \mathrm{~h}$, Orange II-for $48 \mathrm{~h}$ and Congo Red-for $13 \mathrm{~d}$. No complete decolorization of Phenol Red was achieved. Decol orization of Indigo Carmine by means of laccase with

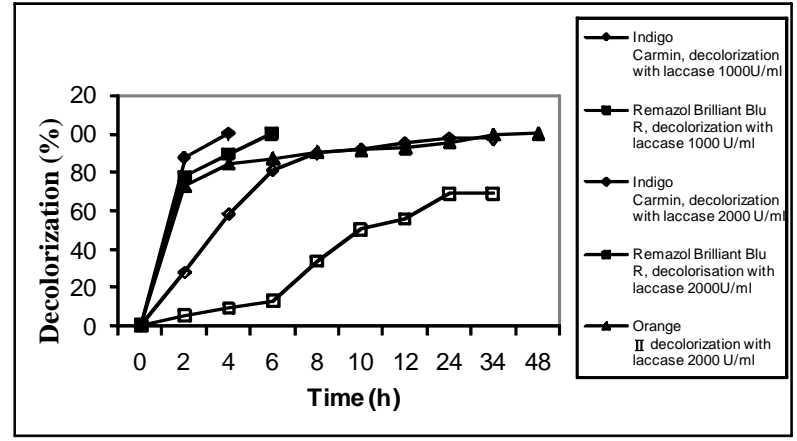

(a)

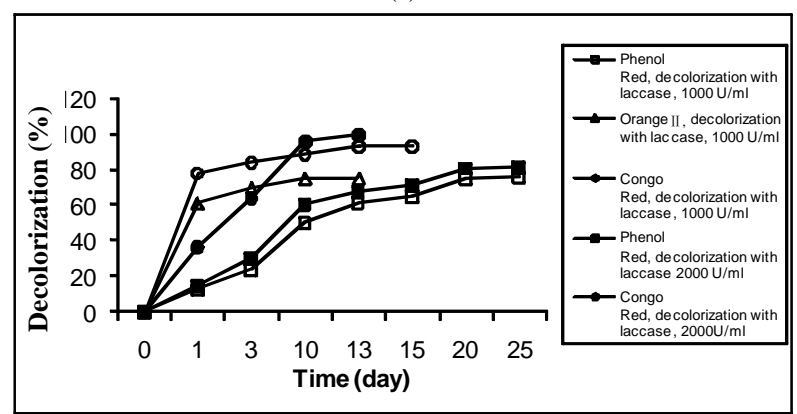

(b)

Figure 3. Decolorization (\%) of various dyes (a), (b) by laccase from $T$. versicolor $1 \mathrm{~A}$

$1000 \mathrm{U} / \mathrm{ml}$ activity was $97.5 \%$ for $34 \mathrm{~h}$, of Remazol Brilliant Blue $\mathrm{R}-69.1 \%$ for $24 \mathrm{~h}$, of Orange II $-75.3 \%$ for $13 \mathrm{~d}$, and of Congo Red-93.4\% for $13 \mathrm{~d}$. In summary, laccase decolorized most readily the indigo dye Indigo Carmine, followed by the anthracene derivative Remazol Brilliant Blue R, while the decolorization of the azo-dyes Orange II and Congo Red was much slower. This could be due to either enzyme inhibition by some products generated in the decoloration process or substrate inhibition. These results differ from those found by Soares et al. [29], who reported that the addition of a redox mediator was necessary for azo-dyes decoloration by a commercial laccase from Novo Nordisk, Denmark (produced by SmF of a genetically modified Aspergillus microorganism). The discrepancy between our results and those from Soares et al. [29] could be due to the difference in fungal species from which the laccase was obtained, the different culture medium and/or the technique used. In addition, the redox potential of laccases varies depending on the laccase source [30], which could also dictate the need of a redox mediator for the decoloration of a particular dye to occur. When a commercial laccase was used, azo-dye decoloration was significantly lower than that attained by laccase from SSF cultures of $T$. versicolor. Since equal doses of laccases were used in the decoloration process, the difference in the decoloration efficiency of the two laccases was most likely due to the difference in laccase isoenzymes produced by the differ- 
ent strains as well as to the difference in specificities to different dyes of diverse structures [31]. In addition, as commented above, it could also be due to the difference in the redox potential of laccases from different microorganisms.

Decolorization of the dyes covered by our study has been reported for laccase produced by Trametes versicolor ATCC 200801, as well, but authors do not specify dye concentrations [32]. Regarding $T$. versicolor CC BAS614, over 50\% degradation of Remazol Brilliant Blue R и Orange 16 for 14 days has been reported [33]. Our data suggests that a more active form of the enzyme allows for the achievement of a complete or at least a higher degree decolorization, as well as for a successful reduction of decolorization time. The influence of laccase activity on dye decolorization is another topic not discussed in scientific literature.

\section{CONCLUSIONS}

The crude enzyme laccase from SSF culture of Trametes versicolor $1 \mathrm{~A}$ was isolated and characterized. The unpurified enzyme was very stable with very good potential for application for industrial wastewater treatment.

On one hand, the results clearly showed the enormous potential of wheat bran, oats straw and beetroot press as a support-substrates for production of laccase at low cost by $T$. versicolor under solid-state conditions. In addition, the laccase produced presented a highly decolorizing ability, especially for indigo and anthracene dyes. This makes laccase from this fungus very attractive for further investigations as well as for its application to different biotechnology areas.

\section{ACKNOWLEDGEMENTS}

This work was supported by national Science Fund, Bulgaria.

\section{REFERENCES}

[1] Thurston, C.F. (1994) The structure and function of fungal laccases. Microbiology, 40, 19-26.

[2] Gianfreda, L., Xu, F. and Bollag, J. (1999) Laccases: A useful group of oxidoreductive enzymes. Bioremediation Journal, 3(1), 1-25.

[3] Call, H.P. and Mucke, I. (1997) History, overview and applications of mediated lignolytic systems, especially laccase-mediator-systems (Lignozym(R)-process). Journal of Biotechnology, 53(2), 163-202.

[4] Bulter, T., Alcalde, M., Sieber, V., Meinhold, P., Schlachtbauer, C. and Arnold, F.H. (2003) Functional expression of a fungal laccase in Saccharomyces cerevisiae by directed evolution. Applied and Environment Microbiology, 69(2), 987-995.

[5] Eggert, C., Temp, U. and Eriksson, K.E.L. (1996) Laccase-producing white-rot fungus lacking lignin peroxidase and manganese peroxidase. ACS Symposium Series,
655, 130-150.

[6] Solomon, E.I., Sundaram, U.M. and Machonkin, T.E. (1996) Multicopper oxidases and oxygenases. Chemistry Reviews, 96(7), 2563-2605.

[7] Schlosser, D., Grey, R. and Fritsche, W. (1997) Patterns of ligninolytic enzymes in Trametes versicolor. Distribution of extra- and intracellular enzyme activities during cultivation on glucose, wheat straw and beech wood. Applied Microbiology and Biotechnology, 47, 412-418.

[8] Swamy, J. and Ramsay, J.A. (1999) Effects of $\mathrm{Mn}^{2+}$ and $\mathrm{NH}^{4+}$ concentrations on laccase and manganese peroxidase production and Amaranth decoloration by Trametes versicolor. Applied Microbiology and Biotechnology, $\mathbf{5 1}$ 391-396.

[9] Pandey, A., Selvakumar, P., Soccol, C.R. and Nigam P. (1999) Solid state fermentation for the production of industrial enzymes. Current Science, 77(1), 149-162.

[10] Murthy, M.V.R., Karanth, N.G. and Raghava Rao, K.S.M.S. (1993) Biochemical engineering aspects of solid-state fermentation. Advances in Applied Microbiology, 38, 99-147.

[11] Ashakumary, L., Selvakumar, P.S. and Pandey, A. (1994) Column fermentor for solid state fermentation. In: Pandey, A., Ed., Solid State Fermentation, Wiley Eastern Limited/Newage International Publishers, 33.

[12] Viniegra-González, G., Favela-Torres, E., Aguilar, C., Romero-Gómez, J., Díaz-Godínez, G. and Augur, C. (2003) Advantages of fungal enzyme production in solid state over liquid fermentation systems. Biochemical Engineering, 13(2-3), 157-167.

[13] Gianfreda, L., Xu, F. and Bollag, J.M. (1999) Enzymatic oxidative transformation of chlorophenol mixtures. Journal of Environmental Quality, 32(1), 63-69.

[14] Xu, F. (1999) Laccase. In: Michael, C.F. and Stephen, W.D., Eds., Encyclopedia of Bioprocess Technology: Fermentation, Biocatalysis, and Bioseparation, Wiley, New York, 1545-1554.

[15] Yaropolov, A.I., Skorobogat'ko, O.V., Vartanov, S.S. and Varfolomeyev, S.D. (1994) Laccase: Properties, catalytic mechanism, and applicability. Applied Biochemistry and Biotechnology, 49(3), 257-280.

[16] Rodriguez, C.S. and Herrera, J.L.T. (2006) Industrial and biotechnological applications of laccases: A review. Biotechnology Advances, 24(5), 500-513.

[17] Camarero, S., Lbarra, D., Marinez, A.T., Romero, J., Gutierrez, A. and Del Rio, J.C. (2007) Paper pulp delignification using laccase and natural mediators. Enzyme and Microbial Technology, 40(5), 1264-1271.

[18] Myasoedova, N.M., Chernykh, A.M., Psurtseva, N.V., Belova, N.V. and Golovleva, L.A. (2008) New efficient producers of fungal laccases. Applied Biochemistry and Microbiology, 44(1), 73-77.

[19] Marbach, I., Harel, E. and Mayer, A.M. (1985) Pectin, a second product for laccase production by Botrytis cinerea. Phytochemistry, 24(11), 2559-2561.

[20] Johanes, C. and Majcherczyk, A. (2000) Laccase activity test and laccase inhibitors. Journal of Biotechnology, 78(2), 193-199.

[21] Mathews, J. and Fink, K. (2001) Numerical methods using MATLAB. Prentice Hall, Upper Saddle River, NJ.

[22] Stanchev, V., Stoilova, I. and Krastanov, A. (2008) Bio- 
degradation dynamics of high catechol concentrations by Aspergillus awamori. Journal of Hazardous Materials, 154(1-3), 396-402.

[23] Zouari-Mechichi, H., Mechichi, T., Dhouib, A., Sayadi, S., Martínez, A.T. and Martínez, M.J. (2006) Laccase purification and characterization from Trametes trogii isolated in Tunisia: Decolorization of textile dyes by the purified enzyme. Enzyme and Microbial Technology, 39(1), 141-148.

[24] Litthauer, D., Vuuren, M.J., Tonder, A. and Wolfaardt, F. (2007) Purification and kinetics of a thermostable laccase from Pycnoporus sanguineus (SCC 108). Enzyme and Microbial Technology, 40(4), 563-568.

[25] Palonen, H., Saloheimo, M., Viikari, L. and Kruus, K. (2003) Purification, characterization and sequence analysis of a laccase from the ascomycete Mauginiella sp. Enztme and Microbial Technology, 33(6), 854-862.

[26] Jordaan, J., Pletschke, B.I. and Leukes, W.D. (2004) Purification and characterization of a thermostable laccase from an unidentified basidiomycete. Enzyme and Microbial Technology, 34(6), 549-554.

[27] Banat, I.M., Nigam, P., Singh, D. and Marchant, R. (1996) Microbial decolourization of textile-dye-containing effluents: A review. Bioresource Technology, 58(3), 217227.
[28] Novotný, C., Rawal, B., Bhatt, M., Patel, M., Sasek, V. and Molotoris, H.P. (2001) Capacity of Irpex lacteus and Pleurotus ostreatus for decolorization of chemically different dyes. Journal of Biotechnology, 89(2-3), 113-122.

[29] Soares, G.M.B., Pessoa de Amorim, M.T. and CostaFerreira, M. (2001) Use of laccase together with redox mediators to decolourize Remazol Brilliant Blue R. Journal of Biotechnology, 89(2-3), 123-129.

[30] Li, K., Xu, F. and Eriksson, K.L. (1999) Comparison of fungal laccases and redox mediators in oxidation of a non-phenolic lignin model compound. Applied and Environmental Microbiology, 65(6), 2654-2660.

[31] Nyanhongo, G.S., Gomes, J., Gübitz, G.M., Zvangya, R., Read, J. and Steiner, W. (2002) Decolourisation of textile dyes by laccases from a newly isolated strain of Trametes modesta. Water Research, 36(6), 1449-1456.

[32] Birhanli, E. and Yesilada, O. (2006) Increased production of laccase by pellets of Funalia trodii ATTC 200800 and Trametes versicolor ATCC 200801 in repeated-batch mod. Enzyme and Microbial Technology, 39(6), 12861293.

[33] Baldrian, P. and Šnajdr, J. (2006) Production of lignolytic enzymes by litter-decomposing fungi and their ability to decolorize synthetic dyes. Enzyme and Microbial Technology, 39(5), 1023-1029. 